\title{
Concepts for Deep Space Travel: From Warp Drives and Hibernation to World Ships and Cryogenics
}

\author{
Martin Braddock* \\ Sherwood Observatory, Mansfield and Sutton Astronomical Society, UK
}

Submission: January 17, 2018; Published: March 14, 2018

*Corresponding author: Martin Braddock, Sherwood Observatory, Mansfield and Sutton Astronomical Society, Coxmoor Road, Sutton-in-Ashfield, Nottinghamshire, United Kingdom, Tel: 07748 761258; Email: projects@sherwood-observatory.org.uk

\section{Introduction}

The routine detection of exoplanets and exomoons, either individually or within their own planetary systems has started to identify potential candidates to harbor or sustain life [1]. Recent discoveries of the TRAPPIST-1 [2] and K2-138 [3] systems illustrate the inevitability of short-listing new worlds for further exploration, by unmanned probes or by manned spacecraft. The ergonomic challenges facing manned spaceflight for both human physiological and psychological adaptation to microgravity are well understood and countermeasures for and mitigation of the effects of microgravity are being developed [4]. One potential solution which would permit sustained human travel in space for many years is the development of systems capable of providing simulated or artificial gravity, in either a continuous or defined intermittent regime. The recent announcement of an International Roadmap for Artificial Gravity Research [5] sets out the ambition for multiple space agencies around the globe to safely develop or adapt a spacecraft to provide a habitat in which astronauts may experience artificial gravity (AG) and the first step towards demonstrating a positive effect of an AG in animals has also recently been published [6] and reviewed [7]. Irrespective of the advances in AG research, we are faced with an as yet, unsurmountable challenge which is the longevity of human life. To date, the limited information we possess shows candidate exoplanets to lie many light years distant, for example candidate exoplanets in the TRAPPIST-1 system are approximately 40 lyr away [2]. For humans to be able to travel to, let alone colonise distantly identified exoplanets, advances in spacecraft propulsion technologies are essential. In addition, extension of the functional human life-span has attracted attention from a number of engineering disciplines and taken together, the 'jig-saw' alignment of four key themes is a requirement for deep space travel (Figure 1).

\section{Strategies to permit deep space travel}

Four areas have been identified which either in isolation or in concert with one or more areas may permit the possibility of deep space travel and are shown in Figure 1. The pros and cons for each strategy described below are illustrated in Table 1 , together with supportive citations.

Table 1: Pros and cons of concepts supporting deep space travel.

\begin{tabular}{|c|c|c|c|}
\hline Concept & Pros & Cons & Citation \\
\hline \multirow{3}{*}{$\begin{array}{l}\text { Develop and utilise super-luminal } \\
\text { (FTL) travel }\end{array}$} & $\begin{array}{l}\text { Proposed distortion of space to } \\
\text { produce 'apparent' FTL travel - } \\
\text { theories of relativity not violated }\end{array}$ & $\begin{array}{l}\text { No known way to create space- } \\
\text { time distortion }\end{array}$ & \multirow{3}{*}{ [8-10] } \\
\hline & $\begin{array}{l}\text { No space debris to collide with } \\
\text { vessel }\end{array}$ & $\begin{array}{l}\text { Extremely high energies would be } \\
\text { required }\end{array}$ & \\
\hline & $\begin{array}{l}\text { No limit to maximum speed } \\
\text { attainable }\end{array}$ & $\begin{array}{c}\text { No feasible way to enter or leave a } \\
\text { warp bubble }\end{array}$ & \\
\hline \multirow{3}{*}{$\begin{array}{l}\text { Develop hibernation or stasis } \\
\text { regimes }\end{array}$} & $\begin{array}{l}\text { Some precedent on a short time } \\
\text { scale in animals and humans }\end{array}$ & $\begin{array}{l}\text { Effects unknown for healthy } \\
\text { individuals }\end{array}$ & \multirow{3}{*}[11,12]{} \\
\hline & \multirow{2}{*}{$\begin{array}{l}\text { Further research driven by } \\
\text { transplant unmet need }\end{array}$} & $\begin{array}{l}\text { Difficult and ethically challenging } \\
\text { to conduct clinical trials in healthy } \\
\text { volunteers }\end{array}$ & \\
\hline & & $\begin{array}{l}\text { Technology not in place to } \\
\text { automate stasis entry and exit }\end{array}$ & \\
\hline
\end{tabular}




\begin{tabular}{|c|c|c|c|}
\hline \multirow{3}{*}{$\begin{array}{l}\text { Employ strategies for engineered } \\
\text { negligible senescence }\end{array}$} & $\begin{array}{l}\text { 'Re-juvenation' technologies may } \\
\text { permit one generation voyages }\end{array}$ & $\begin{array}{l}\text { Total rejuvenation may require } \\
\text { multiple therapies }\end{array}$ & \multirow{3}{*}[14,15]{} \\
\hline & \multirow{2}{*}{$\begin{array}{l}\text { Stem cell therapies may drive } \\
\text { future potential }\end{array}$} & $\begin{array}{l}\text { Individual components of ageing } \\
\text { may need to be attenuated } \\
\text { individually to establish proof-of- } \\
\text { principle }\end{array}$ & \\
\hline & & $\begin{array}{l}\text { Rejuvenation may need } \\
\text { continuous therapy throughout } \\
\text { space travel. }\end{array}$ & \\
\hline \multirow{3}{*}{$\begin{array}{l}\text { Engage in multigenerational } \\
\text { voyages on world ships }\end{array}$} & $\begin{array}{l}\text { May accommodate limitations } \\
\text { in foreseeable propulsion } \\
\text { technologies }\end{array}$ & $\begin{array}{l}\text { Cost to construct and maintain a } \\
\text { world-ship currently prohibitive }\end{array}$ & \multirow{3}{*}[16,17]{} \\
\hline & \multirow[b]{2}{*}{$\begin{array}{l}\text { High number of colonists } \\
\text { maximises chances of success }\end{array}$} & $\begin{array}{l}\text { Moral and ethical challenges to } \\
\text { human life commitment in space }\end{array}$ & \\
\hline & & $\begin{array}{l}\text { Development of new, faster } \\
\text { technology on Earth may bypass } \\
\text { world-ship concept when in } \\
\text { transit }\end{array}$ & \\
\hline \multirow{3}{*}{$\begin{array}{l}\text { Develop cryogenic freezing } \\
\text { technologies }\end{array}$} & $\begin{array}{l}\text { Accommodates all limitations on } \\
\text { current space travel propulsion } \\
\text { and voyage duration }\end{array}$ & $\begin{array}{l}\text { Effects on physiology and central } \\
\text { nervous system function not yet } \\
\text { demonstrated in higher animals }\end{array}$ & \multirow{3}{*}[18-20]{} \\
\hline & $\begin{array}{l}\text { Precedent for vitrification and } \\
\text { rewarming of functional tissue }\end{array}$ & $\begin{array}{l}\text { Effects unknown for healthy } \\
\text { individuals }\end{array}$ & \\
\hline & $\begin{array}{l}\text { Precedent for organism } \\
\text { restoration after freezing }\end{array}$ & $\begin{array}{l}\text { Difficult and ethically challenging } \\
\text { to conduct clinical trials in healthy } \\
\text { volunteers }\end{array}$ & \\
\hline
\end{tabular}

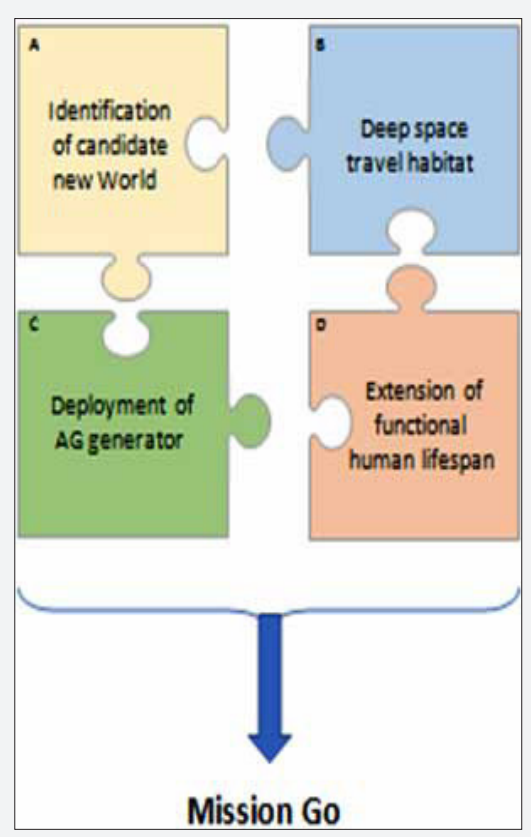

Figure 1: Alignment of themes to support interstellar travel. A) Identification of candidate new world,

B) Deep space travel habitat,

C) Deployment of artificial gravity generator and

D) Extension of functional human life-span.

Warp drive super-luminal, faster than light (FTL) travel

This is a very speculative, but possibly valid, solution of the Einstein field equations which propose to perturb the fabric of space-time in a way which theoretically may allow FTL travel. Such a methodology would cause the space ahead of an object to contract while the space behind it would expand, creating a 'warp' bubble of flat space. Known as the Alcubierre metric after its inventor [8], it allows for the creation of a warp bubble in a previously flat region of space-time to move away, effectively at speeds that exceed the speed of light. As a spacecraft is not, per se moving in, but rather within the bubble, time dilation would not apply and thus the laws of relativity are conserved. FTL in this sense refers to movement within the bubble: a light beam would move faster than the space ship within the bubble end the ship could reach its destination faster than a beam of light that was travelling outside the warp bubble. Although in theory this route of travel would mean no encounters with space debris, there is no theoretical way to create a warp bubble which would likely require immense energies and a controlled way to gain access and secure departure at precisely the right time. NASA had started to assess the feasibility of warp drive creation [9] and although theoretically attractive, development of technology for advanced propulsion by other routes is essential. One such example is the conceptual proof of principle of an engine which does not require any propellant and uses radio-frequency microwaves within a vacuum to generate forward impulsive thrust [10].

\section{Hibernation}

The potential for human beings to be in a state of hibernation or stasis has long been recognized from the animal kingdom where animals, including all types of mammal have an innate body clock which enables them to safely and spontaneously 
enter and leave hibernation. In humans, during cardiac surgery or acute brain trauma, controlled hypothermia which reduces metabolism is widely used in clinical practice [11]. Although seldom used for more than several hours, there exist anecdotal accounts of humans withstanding extreme temperatures for several weeks with little or no food. However, in patient cases of increased intracranial pressure that is refractory to normal treatment methods, humans have been placed in therapeutic hypothermia for up to 14 days [12]. Should human hibernation be possible for long periods of time, the issue of tissue atrophy in an environment of microgravity would pose a potentially great threat to human physiology at the end of the hibernation period. It is possible for this risk to be mitigated by the habitat providing $\mathrm{AG}$, and in a state of hibernation, neuro-vestibular perturbations such as the tumbling sensations experienced in the Coriolis cross-coupling effect [13] may not be an issue. Nevertheless, despite the challenges, the potential for human stasis to support deep space travel is a very active area of research which benefits from technology which is being developed on Earth for the treatment of acute injury [12].

\section{Strategies for Engineered Negligible Senescence (SENS)}

A controversial though scientifically thought-provoking field is that of 'curing' ageing to permit a functional human life span of centuries. Pioneered by the biogerontologist Aubrey de Grey, it proposes to counteract the effects of ageing by understanding the ageing process and implementing a new wave of rejuvenation therapies [14]. Some of such therapies [15] to date, almost exclusively in the domain of the biotechnology industry aim to remove senescent cells, restore and replenish the immune system which may prevent cancer, remove amyloid and other aggregates which are associated with the onset of Alzheimer's disease and clear glucose pane cross-links which may be associated with blood vessel stiffness. In addition the use of stem cells to either replace quiescent stem cells or provide a localised platform for tissue repair in situ also form part of the SENS approach [15].

\section{World Ships and Multi-Generational Voyages}

The concept of a World Ship is to construct a self-contained and self-sustaining gigantic space vessel. As originally intended, it would travel at a fraction of a percentage of the speed of light and be capable of sustaining a population of astronauts for centuries [16]. In part, the concept may address two long term goals. The first would be to maintain a human colony in space, capable of procreation with a viable population that maintains genetic diversity and has a crew sufficiently large enough to withstand at least one natural disaster [17]. The second goal, which is a consequence of the first, is to maintain the colony for a long enough duration to permit travel to a candidate exoplanet in the first instance to explore and in the second to consider suitability for colonisation.

\section{Cryogenics}

The concept of cryogenics may in part be viewed as an extension of hibernation. However, there are many more risks involved in the vitrification and rewarming of a human being after a defined period of time. The concept has in part been boosted by several developments. Recently, in support of the field of organ transplantation, radio-frequency energized nano-warming of human cells and porcine arteries and porcine aortic value leaflet tissues of $1-50 \mathrm{ml}$ volume has been demonstrated using iron oxide nanoparticles. Importantly nano-warming yielded cell and tissue viability that matched control conditions and biomechanical testing displayed no significant biomechanical property changes in blood vessel length or elastic modulus after nano-warming compared with untreated fresh control porcine arteries [18]. Earlier studies which appear to demonstrate that, albeit in a simple organism, memory can be retained after cryopreservation have been conducted in the nematode worm Caenorhabditis elegans. Using olfactory printing demanding locomotion to benzaldehyde, worms were shown to retain their memory of this stimulus which was unchanged by the process of vitrification or by slow freezing [19]. Moving up the evolutionary scale, a way to preserve the neural circuits of an intact rabbit brain for long-term storage using a combination of chemical fixation and cryogenic cooling has been demonstrated [20] which may lead to further developments in cryogenic freezing and rewarming of whole animals.

\section{Conclusion}

Since the discovery of the first exoplanet in 1992 [21] and the first exoplanet orbiting a sun-like star in 1995 [22], there have been 3584 exoplanets identified as of 16th January 2018 in 2668 solar systems of which 883 are terrestrial in composition [1]. Of those 3584, 53 are believed to lie within the habitable zone of their star and have a constitution appropriate to that which is needed to support life [23], at least from our understanding of life on Earth. Although manned travel to those planets demands technology unavailable today, progress is being made and although this achievement may be many hundreds of years distant, travel to and colonization of bodies within our solar system will mark a significant step forward to preparing for future deep space travel.

\section{Acknowledgement}

Martin Braddock is a member of the Mansfield and Sutton Astronomical Society (MSAS) a Fellow of the Royal Society of Biology and a Fellow of the Royal Astronomical Society. MSAS is a registered charity, number 51813 and was founded in 1970 to foster interest in astronomy in Ashfield, Nottinghamshire, United Kingdom and surrounding district.

\section{References}

1. https://exoplanets.nasa.gov/ 


\section{Current Trends in Biomedical Engineering \& Biosciences}

2. Gillon M, Triaud AHMJ, Demory BO, Jehin E, Agol E, et al. (2017) Seven temperate terrestrial planets around the nearby ultra cool dwarf star TRAPPIST-1. Nature 542: 456-460.

3. Christiansen JL, Crossfield IJM, Barentsen G, Lintott CJ, Barclay T, et al (2018) The K2-138 system: a near resonant-chain of five sub-Neptune planets discovered by citizen scientists. Astron J 155(2): 11.

4. Braddock M (2017) Ergonomic challenges for astronauts during space travel and the need for space medicine. J Ergonomics 7(6): 1-10.

5. Clement G (2017) International roadmap for artificial gravity research Npj Microgravity 3(29).

6. Shiba D, Mizuno H, Yumoto A, Michihiko Shimomura, Hiroe Kobayashi, et al. (2017) Development of new experimental platform 'MARS'multiple artificial-gravity research system - to elucidate the impacts of micro/partial gravity on mice. Scientific Reports 7(10837).

7. Braddock M (2017) Artificial gravity: small steps on the journey to the giant leap. J Space Explor 6(3): 137-145.

8. Alcubierre M (1994) The warp drive: hyper-fast travel within general relativity. Class Quantum Grav 11: L73-L77.

9. White H (2012) Warp field mechanics 101, NASA Johnson Space Center, Texas, USA.

10. White H, March P, Lawrence J, Vera J, Sylvester A, et al. (2016) Measurement of impulsive thrust from a closed radio-frequency cavity in vacuum. J Propul Power 33(4): 830-841.

11. Luscombe M, Andrezejowski JC (2006) Clinical applications of induced hyperthermia. BJA 6(1): 42-44.

12. Schaffer M, Bradford J, Talk D (2016) A feasible, near-term approach to human stasis for long-duration deep space missions. $67^{\text {th }}$ Internationa Astronautical Congress (IAC), Guadalajara, Mexico, USA, pp. 1-17.
13. Guedry FE, Benson AJ (1977) Coriolis cross-coupling effects: disorientating and nauseogenic or not? Naval Aerosp Med Res Lab.

14. http://www.senescence.info/sens.html

15. https://www.fightaging.org/archives/2016/11/predicting-theorder-of-arrival-of-the-first-rejuvenation-therapies/

16. Hein AM, Pak M, Putz D, Buhler C, Reiss P, et al. (2012) World shipsarchitectures and feasibility revisited. J Brit Interplan Soc 65: 119-133.

17. Smith CM (2014) Estimation of a genetically viable population for multi-generational interstellar voyaging: Review and data for project Hyperion. Acta Astronautica 97: 16-29.

18. Manuchehrabadi N, Gao Z, Zhang J, Ring HL, Shao Q, et al. (2017) Improved tissue cryopreservation using inductive heating of magnetic nanoparticles. Science Trans Med 9(379): eaah4586.

19. Vita MN, Barranco D (2015) Persistence in long-term memory in vitrified and revived Caenorhabditis elegans. Rujuvenation Res 18(5): 458-463.

20. McIntyre Rl, Fahy GM (2015) Aldehyde-stabilised cryopreservation Cryobiology 71(3): 448-458.

21. Wolszczan A, Frail DA (1992) A planetary system around the millisecond pulsar PSR1257+12. Nature 355: 145-147.

22. Mayor M, Queloz D (1995) A Jupiter-mass companion to a solar-type star. Nature 378: 355-359.

23. http://phl.upr.edu/projects/habitable-exoplanets-catalog

Your next submission with Juniper Publishers
will reach you the below assets
- Quality Editorial service
- Swift Peer Review
- Reprints availability
- E-prints Service
- Manuscript Podcast for convenient understanding
- Global attainment for your research
- Manuscript accessibility in different formats
( Pdf, E-pub, Full Text, Audio)
- Unceasing customer service
Track the below URL for one-step submission
https://juniperpublishers.com/online-submission.php

